УДК: $378.016:[80+33+002.1]$

DOI:

Марія Якубовська, кандидат філологічних наук, доиент кафедри інформаційної, бібліотечної та книжкової справи Української академії друкарства Марія Стахів, кандидат педагогічних наук, дочент кафедри початкової та дошкільної освіти Львівського національного університету імені Івана Франка

\title{
ТРАДИЦІЇ ІВАНА ФЕДОРОВИЧА У СУЧАСНОМУ ДУХОВНОМУ ПРОСТОРІ: ТРАДИЦІЇ ТВОРЕННЯ УКРАЇНСЬКИХ ПІДРУЧНИКІВ
}

У статті порушено проблеми науково-теоретичних аспектів алгоритму інновачійних змін у системі сучасної иколи, в основі яких лежить відповідь сучасної педагогічної науки викликам новітньої доби, коли педагогіка, виконуючи свої історичні завдання, створює передумови для утвердження якісних інноваційних процесів педагогічної взаємодії у системі “освіта - суспільство”, щуо становить основи гуманітарної безпеки нашого суспільства.

Якісно новий тип підручників - важлива педагогічна проблема. Підручник є важливим засобом у формуванні професійної компетентності сучасного фахівця. Роль підручника у системі вищої професійної школи зростає у час інновачійного осмислення новітніх иляхів духовного поступу людства. Інноваційна система викладу навчального матеріалу сприяє ефективному його засвоєнню студентами.

Ключові слова: культурологічна компетентність; культурологічний світогляд; науковий дискурс, інваріантність дискурсу; культурологічна свідомість; мистецтво спілкування; культурологічне середовище; психологічний захист особистості.

Jim. 6.

Mariya Yakubovska, Ph.D.(Philology), Associate Professor of the Information, Library and Book Business Department Ukrainian Academy of Printing, Mariya Stakhiv, Ph.D.(Pedagogy), Associate Professor of the Elementary and Preschool Education Department Lviv Ivan Franko National University

\section{TRADITIONS OF IVAN FEDOROVYCH IN THE MODERN SPIRITUAL SPACE: TRADITIONS OF CREATION OF UKRAINIAN TEXTBOOKS}

The article deals with the problems of scientific-theoretical aspects of algorithm innovative changes algorithm in system of present schools, in basis of which there is the nowadays pedagogical science's answer to challenges of New Era, when pedagogy, performing its historical tasks, creates precondition for that have been approved quality innovative processes of pedagogical interactions in system "Education - Society", what is to establish the basis of human security of our organization. A qualitatively new type of textbooks is an important pedagogical problem. The textbook is an important tool in shaping the professional competence of a modern specialist. The role of the textbook in the system of higher vocational education grows in the period of innovative thinking of the newest paths of spiritual progress of humanity. Innovative teaching material system contributes to its effective assimilation by students. In particular, the role of educational literature in the period of information explosion is growing. National pedagogy has great traditions in the creation of textbooks. Ivan Fedorovych in Lviv issued "Bukvar", which became the first in the world.

On the basis of qualitative updating of the formation of textbooks the problems of updating and introducing the innovative content of education, reformatting the system of requirements to the knowledge and skills of a high school student, the maximum interaction between practice and study, which are formed on the basis of well thoughtout culturological influence are considered, the system of formation of culturological competence is considered, which is a consequence of the symbiosis of the efforts of all units educationally - the educational activities of the modern school. The system of formation of human personality in the system of personally oriented education is considered. Culturological approach in the creation of scientific and cognitive texts is the need to develop the student's need for self-knowledge, self-study activities.

Keywords: cultural competence; cultural outlook; scientific discourse; discourse invariance; cultural consciousness; art of communication; cultural environment; psychological protection of the individual.

A ктуальність проблеми. У статті порушено проблеми науковотеоретичних аспектів алгоритму інноваційних змін у системі сучасної школи, в основі яких лежить відповідь сучасної педагогічної науки викликам новітньої доби, коли педагогіка, 
виконуючи свої історичні завдання, створює передумови для утвердження якісних інноваційних процесів педагогічної взаємодії у системі “освіта - суспільство”, що становить основи гуманітарної безпеки нашого суспільства. Якісно новий тип підручників - важлива педагогічна проблема. Підручник є важливим засобом у формуванні професійної компетентності сучасного фахівця. Роль підручника у системі вищої професійної школи зростає у час інноваційного осмислення новітніх шляхів духовного поступу людства. Інноваційна система викладу навчального матеріалу сприяє ефективному його засвоєнню студентами. Особливо зростає роль навчальної літератури в пору інформаційного вибуху. Національна педагогіка має великі традиції у творенні підручників. Іван Федорович у Львові видав “Буквар”, який став першим у світі підручником.

Аналіз останніх досліджень і публікацій. Незважаючи на актуальність даної проблеми, на даний час маємо небагато досліджень, які б розкривали роль підручника у системі оновленої парадигми сучасної школи. В умовах творення національної школи більше уваги приділяється питанням змістового наповнення навчальних посібників. Практика сучасної педагогічної школи свідчить, що, поруч із друкованим підручником, останнім часом усе більше практикується функціонування електронного підручника. На даний час все ще немає наскрізного дослідження даної проблеми як наукового явища. Теоретичною базою для дослідження було взято праці І.Д. Беха, В.П. Андрущенка, В.Г. Креміня, С.У. Гончаренка, I.А. Зязюна, Н.Г. Ничкало, В.О. Огнев'юка, М.Б. Євтуха та ін., у яких розкриваються філософського-психологічні основи формування світогляду сучасного студента і проводиться дискурс професійного становлення та когнітивного розвитку студента. Акад. І.Д. Бех накреслив алгоритм формування духовноекзистенційних основ особистості у системному відтворенні “від культури мислення до культури духовного переживання”, у якому наголошується на інноваційних методах науково-методичної діяльності сучасної української школи.

У статті “Духовна особистість у контексті освітніх викликів” видатний учений І.Д. Бех наголошує: "Багатовікове відчуження людини від справжніх духовних цінностей призвело до кризових явищ, пов'язаних із занепадом духовноморальних ідеалів, посиленням зла і насильства. Девальвація духовних цінностей суттєво вплинула на посилення тенденції зростання жорстокого індивідуалізму, прагматизму, зверхнього ставлення до інших людей та приниження їхньої гідності, зневаги до рідної культури та історикокультурних традицій” $[1,3]$.

Доктор філологічних наук Н.В. Зелінська підняла питання творення якісно оновлених підручників, у яких виклад навчального матеріалу подається в оновленому варіанті, коли поруч 3 текстами наукового характеру є присутні матеріали, котрі сприяють емоційному засвоєнню навчального матеріалу. Поетика наукового підручника, за концептуальними засадами проф. Н.В. Зелінської, становить частину великої інноваційної системи модернізації сучасної вищої школи, яка змінює не просто стиль викладання, а закладає основи нового комунікативного діалогу між студентами і викладачем. Так як “для кожного типу навчальних закладів видаються підручники, які відповідають програмам і завданням цього закладу, віковим та іншим особливостям тих, хто навчається" [2, 260].

Дані традиції були започатковані у друкованих книгах Івана Федоровича, зокрема у його “Букварі”, який був першою навчальною книгою у європейському духовному просторі. За ініціативи благодійного фонду "Відродження" історикокультурної спадщини України ім. Героя України Б.Г. Возницького у 2014 році перевидано “Буквар” Івана Федоровича в автентичному варіанті. Аналіз підручника дає змогу стверджувати, що на теренах України з часів Івана Федоровича була започаткована традиція творення інноваційних підручників.

Мета статті - розглянути проблеми формування підручників сучасних закладів вищої освіти, розкрити взаємозв'язок між проблемами духовного оновлення суспільства, багатогранним розвитком людської індивідуальності та системою творення інноваційної парадигми сучасних підручників. Частково розглянути психологічні процеси, які відбуваються у молодіжному середовищі, показати вплив інноваційних змін у сучасній вищій професійній школі на формування культурологічного світогляду молодої людини.

Матеріали і методи дослідження: під час дослідження було використано компаративний, історико-логічний, синергетичний методи. Зазначений методологічний підхід дозволив проаналізувати системне творення гуманітарної безпеки суспільства як складової загальної гуманітарної парадигми сучасної інноваційної складової науково-педагогічної діяльності закладів вищої освіти негуманітарного профілю.

Виклад основного матеріалу дослідження. 1. Науково-методичні засади творення оновлених підручників сучасної особистісно зорієнтованої освіти. 


\section{ТРАДИЦІї ІВАНА ФЕДОРОВИЧА У СУЧАСНОМУ ДУХОВНОМУ ПРОСТОРІ ТРАДИЦІЇ ТВОРЕННЯ УКРАЇНСЬКИХПДРУЧНИКІВ}

Для успішної реалізації завдань сучасної особистісно зорієнтованої освіти важливою $є$ формування культурологічної компетентності вихованців, яка складає основу гуманітарної безпеки сучасності, складовими частинами якої $€$ інформаційна та психологічна безпека сучасного суспільства. Гармонія соціуму залежить від гармонійного становлення особисті на всіх етапах навчальної діяльності. У даних процесах важливим є дослідження науково-теоретичних аспектів формування алгоритму творення якісно оновлених підручників. Вивчення досвіду минулого дає змогу утверджувати якісно оновлені форми функціонування підручника у сучасному освітньому просторі. Актуальними є також дослідження вироблення взаємозв'язку системи формування культурологічної компетентності вихованців та системи творення підручників якісно нового типу. Підручник стає важливою складовою у системі форм організації навчання, які “забезпечують свідоме володіння навчальним матеріалом, відповідними уміннями та навичками" [3, 17].

Система квантового мислення творить нові асоціативні зв'язки на стикові традиційних наук, торуючи шлях не лише для народження нових галузей наукового дослідження, а і для нових інноваційних напрямків у системі наукових досліджень сучасності. Даний напрямок науковий досліджень - якісно новий розвиток сучасної професійної освіти, який передбачає оновлення змісту і форм викладу навчального матеріалу. Разом зі зміною парадигми сучасної особистісно зорієнтованої освіти буде видозмінюватися і архетип творення якісно нових підручників. Для якіснішого засвоєння навчальних завдань і 3 метою формування якісно нового фахівця, котрий буде працювати в умовах інноваційного розвитку суспільства дані дослідження будуть набувати щораз більшого значення.

Якісно новий тип підручників - важлива педагогічна проблема, без вирішення якої неможливим $\epsilon$ формування професійної компетентності сучасного фахівця, системне вивчення якої включає такі аксіологічні принципи реалізації. Г. Ващенко у праці “Хвороба в галузі національної пам'яті” наголошує: “Особливо потрібна творча уява українській молоді. Історія поставила перед нею складні й трудні завдання: вибороти волю для своєї Батьківщини, піднести ііі зі стану руїни, розбудувати її культуру й цивілізацію, поставити іії в ряд передових держав світу. Для цього потрібна нашій молоді тверда непохитна воля, знання, технічна озброєність і міцна творча уява" $[4,52]$.
Ми живемо у час інноваційного осмислення новітніх шляхів духовного поступу людства: від творення нової культурологічної парадигми епохи до пошуків шляхів модерної реалізації даної культурологічної парадигми. Проблема змісту навчальних програм як для загальноосвітньої, так і для вищої школи $є$ надзвичайно актуальною, але у пору інформаційного вибуху, численних інноваційних технологій людство переживає епоху перенасичення інформацією. У цьому ущільненому інтелектуальному просторі виникають ризики “"загубитися”, “потонути” у морі інформації, піти по хибному шляху тощо. Ці ризики становлять собою лише першу частину особливостей сучасного освітньо-інтелектуального сегменту.

Набагато складнішою є потреба донесення потрібної інформації у чітко структурованому, логічно осмисленому вимірі. Тому пошуки інноваційного викладу навчального матеріалу $є$ проблемою, яка виходить за рамки навчального процесу, становить важливу основу творення культурологічної парадигми сучасності. Система творення інноваційних підручників тісно пов'язана із проблемами пізнання. "Пізнання є специфічною, вищою формою відображення. Воно здатне виходити за межі наявного стану речей, тобто відображати не тільки сучасне, а й майбутнє; не лише дійсне, а й численні можливості - конкретні й абстрактні - для вибору тієї з них, що найбільше відповідає інтересам людини" [2, 261]. Оскільки у навчальному закладі проблеми удосконалення дидактичного викладу навчального матеріалу є важливою науково-педагогічною системою, тому застосування синенергетичних, культурологічних, поетичних викладів створюють якісно новий архетип у системі творення навчального процесу.

2. Творча професійна діяльність Івана Федоровича у системі творення “Букваря" першого підручника на теренах Європи.

В основі педагогічних інноваційних пошуків лежить потреба створювати основу для творення багатоманітних засобів для досягнення якісних результатів. Культурологічна спрямованість дасть можливість творення інтеграційних процесів у системі інноваційних пошуків. Традицію творення першого підручника можна розглянути на прикладі творчої професійної діяльності Івана Федоровича.

Львові у 1574 році відбувається унікальна подія: надруковано перший у світі підручник - “Буквар”. Його творець - видатна постать в історії культур східнослов'янських народів, гуманіст і просвітитель XVI ст., видавець, майстер книжного мистецтва, письменник, педагог, художник-гравер Іван Федорович. У 2015 році за 


\section{ТРАДИЦІЇ ІВАНА ФЕДОРОВИЧА У СУЧАСНОМУ ДУХОВНОМУ ПРОСТОРІ: ТРАДИЦІЇ ТВОРЕННЯ УКРАЇНСЬКИХПДРУЧНИКІВ}

сприянням благодійного фонду “Відродження історико-культурної спадщини України ім. Героя України Б.Г. Возницького" було перевидано “Буквар" І. Федоровича й передано освітньонавчальним закладам. Водночас 3 нагоди цієї визначної культурно-освітньої події Національною академією наук України, спільно з Інститутом українознавства ім. І. Крип'якевича (м. Львів) було організовано й проведено науково-практичну конференцію.

Іван Федорович усе життя йшов за високим покликанням, за бажанням увічнити філософськодуховну субстанцію Слова у буквеній парадигмі. Адже слово має духовну й матеріальну оболонку: здатність побачити слово, написаним чи надрукованим на папері, що в числі досягнень людства було до порівняння, приміром, 3 винаходом колеса.

Іван Федорович прагнув, аби слово постало набутком людства, аби слово увійшло не лишень в оселю заможних людей, але й під кожну селянську стріху. Український першодрукар усім серцем бажав, аби кожна дитина була письменною. Відтак “Буквар" постав уособленням реалізації цих прагнень. Книга Івана Федоровича несла на вівтар людства ідеали добра, справедливості, духовності. Побутує думка, що його друкарню навмисно підпалили чи то конкуренти, чи недоброзичливці. Адже справа друкаря Івана Федоровича на той час уже убезпечувала не лишень матеріальні статки, але й слугувала духовним джерелом єднання суспільства.

Книги Івана Федоровича були адресовані не лишень маленьким читачам, але й батькам, адже в тісному родинному взаємозв'язку i взаєморозумінні друкар бачив силу народу, а відтак і людства. Г. Ващенко наголошував: “Серед суспільства існує думка, що фантазія потрібна лише в мистецькій творчості. Така думка дуже помилкова. Крім мистецтва, творча фантазія виступає як рушійна сила у відкриттях, винахідництві” $[4,260]$.

Про парадигму людських взаємин Іван Федорович пише у “Букварі”, адже поруч із навчанням грамоти формування архетипу людської індивідуальності та людських взаємин - це є чи не найважніша дидактична настанова Івана Федоровича.

Можемо стверджувати, що педагогічна книга Івана Федоровича була новаторською за змістом і за формою. Друкар переконливо просить, аби батьки ніколи не били дітей, бо це не лише принижує людську гідність, але і вселяє у молоді душі озлобленість, зневіру, черствість.
За переконаннями Івана Федоровича, єдиним засобом порозуміння між людьми та цивілізаціями залишається слово як духовна субстанція, котра $\epsilon$ носієм матеріалізованої людського світогляду.

Життя Івана Федоровича - це ще одна філософсько-дидактична настанова, оскільки він на конкретних власних звершеннях і власного життєвого шляху доводить, що кожна особистість має сягнути реалізації своїх задумів. Доля Івана Федоровича пов'язана із багатьма народами: навчався у Ягеллонському університеті (Краків, Польща), жив і працював в Україні (Львів, Острог), в Росії та в Білорусії.

Спроба пояснити родове походження Івана Федоровича увінчалася успіхом завдяки друкарському клеймові, яке він ставив на книгах, що ці було надруковано у його друкарні. Як з'ясували дослідники, абсолютно схожий знак $є$ в геральдичному збірнику XVI століття. Було встановлено, що друкарський знак Івана Федорова (на червоному полі срібна буква $\mathrm{S}$ під золотою стрілкою) є дуже схожим на герб роду Шриняви (в іншому прочитанні Сриняви: на червоному полі срібна буква $\mathrm{S}$ під золотим хрестом).

Цей факт свідчить про те, що Іван Федорович був шляхтичем і належав до знатного роду, адже цей герб було покладено в основу багатьох відомих родів Великого князівства Литовського. Срібна стрілка над буквою “S” $є$ на гербі тільки одного роду - білоруських шляхтичів, які носили прізвище Рогоза. Саме цей родовий герб і дає підстави стверджувати, що друкар Іван Федорович був білоруським шляхтичем на ім'я Іван Федорович Рогоза.

Для оформлення “Апостола” Іван Федорович використовує зображення євангеліста Луки 3 видання Біблії 1540 року чеською мовою. Післямова Івана Федоровича, написана у кращих традиціях епохи Відродження, свідчить і про талант письменника, і про обдарування педагога. Ця праця стає своєрідною підготовкою до видання “Букваря".

За “Букварями” Івана Федоровича навчалося грамоті не одне покоління українців: від Тараса Шевченка чи Богдана Хмельницького, Григорія Сковороди чи Івана Котляревського, Юрія Федьковича чи Пантелеймона Куліша до Івана Франка та Лесі Українки. Своєю жертовною працею Іван Федорович закладав підвалини формування духовної еліти багатьох поколінь. За свідченням науковців, “Буквар” Івана Федоровича потрапив із України за кордон ще в першій половині XVII ст.

Традиції Івана Федоровича продовжувалися 


\section{ТРАДИЦЇ̈ ІВАНА ФЕДОРОВИЧА У СУЧАСНОМУ ДУХОВНОМУ ПРОСТОРІ ТРАДИЦІї ТВОРЕННЯ УКРАЇНСЬКИХПДРУЧНИКІВ}

Братськими друкарнями Києва, Львова, Вільно, Могильова. Зважений науково-методичний аналіз “Букваря" Івана Федоровича дає змогу стверджувати, що першодрукар добре володів основами дидактики. Школяр, за системою Івана Федоровича, виступає в ролі активного співрозмовника. Саме в таких формах активної навчальної діяльності школяра відбувається активне становлення особистості дитини, яка в процесі навчання бере участь в активних видах і формах діяльності.

Структура “Букваря” Івана Федоровича передбачає логічно-послідовне ознайомлення школяра iз багатством навколишнього мовленнєвого світу: виділення студійованого звуку, звуків; активне вимовляння виділених звуків. Така зважена й філологічно мудра та науково обгрунтована система подачі матеріалу у “Букварі” Івана Федоровича свідчить про його широку ерудицію і гуманітарні знання.

Одне $з$ найголовніших завдань підручника вчити дитину самостійно здобувати знання. Підручник Івана Федоровича побудовано за індуктивним принципом “від часткового до загального”. Саме цей принцип дає можливість забезпечити функціональний підхід до вивчення мовних і мовленнєвих явищ.

Мовно-теоретична змістова лінія спрямована на засвоєння елементарних, але при цьому науково правильних знань про мову, про елементи iii системи, набуття на основі цих знань практичних умінь.

Для кращого засвоєння навчального матеріалу Іван Федорович подає азбучні акровірші - тексти для самостійного читання. Такі тексти є надзвичайно важливими під час навчання школярів. У “Букварі” Івана Федоровича на кожну літеру абетки підібрані вислови зі Святого письма та поміщено унікальні тексти, автором яких був, можливо, сам друкар.

“Буквар” Івана Федоровича покликаний був не лише навчити школяра грамоті, а й забезпечити загальний розвиток дитини: сформувати дидактичні уміння і навички; виробляти відповідний темп, правильність, розуміння і виразність читання, уміння відчувати слово; виховувати почуття любові до мови, батьків; постійно підтримуючи і розвиваючи у школярів бажання вчитися. Таким чином, на прикладі "Букваря" Івана Федоровича ми бачимо, як великою особистою працею учений, просвітитель творив духовне обличчя своєї епохи.

Традиції Івана Федоровича у виданні підручників мали продовження у наступні епохи. Достатньо згадати буквар Лаврентія Зизанія
(Вільно, 1596) і аналогічний йому буквар В. Бурцева (Москва, 1634). У XVII ст. найкращим був ілюстрований буквар Каріона Істоміна (1694).

Україні у середині XIX століття з моменту підйому духовного життя епохи до укладання “Букварів" зверталися Тарас Шевченко, Юрій Федькович, Пантелеймон Куліш. У цьому переліку особливе місце посідає остання прижиттєва книжка Тараса Шевченка - “Буквар південноруський”, яка вийшла великим накладом коштом самого автора.

Освіта є тими дієвими чинниками розвитку людської цивілізації, від яких залежить конструктивний розвиток людства. Духовний світ, в освітніх системах, у даному випадку на прикладі “Букваря” Івана Федоровича, наче матеріалізується у реаліях щоденного життя. Таким чином, руйнація чи, навпаки, утвердження духовного світу є тим важливим чинником у загальному розвитку світової цивілізації.

Іван Федорович усвідомлював свої завдання, розуміючи, який вплив матиме книга на людську свідомість. Культурологічне виховання засобами слова відіграє надважливу роль у духовному та професійному становленні молодого покоління. Як показує досвід видатного першодрукаря Івана Федоровича, найбільше через слово кожна людська індивідуальність повинна мати змогу розкрити свої творчі здібності.

3. Модернізація наукового тексту у системі викладу матеріалу.

Основою гуманітарної безпеки суспільства становлять інформаційна та психологічна безпека, які $є$ водночас структурними елементами гуманітарної безпеки і перебувають із нею у тісному взаємозв'язку. Щоб пізнати суть епохи, потрібно осмислити духовні набутки, створені нею.

Аналізуючи синенергетичний ряд модернізації наукового тексту, усвідомлюєш, що тільки таким чином можна створювати відповідне культурологічне напруження (силове синенергетичне поле навчального процесу), яке формує відповідну культурологічно-емоційну ауру у системі навчального процесу. Такий виклад матеріалу дозволяє не лише активізувати мисленнєву діяльність студентів, а і сприяє якісному засвоєнню навчального матеріалу. Як справедливо наголошує Леонід Ушаков у книзі “Що таке українська література": “І, говорячи про українців, Ганкевич стверджує: “Коли про Бога та світ українець виробив у власній свідомості ясні поняття, то найважливішим питанням людського думання і досі $є$ для нього успадковане від греків “пізнай себе” [5, 283]. 
Індивідуальний характер у системі особистісно зорієнтованого наукового тексту не заперечує об'єктивного викладу матеріалу, а лишень поглиблює його за допомогою включення суб'єктивного чинника. Адже за новітніми інноваційними психолого-філософськими підходами сила наукового пізнання полягає у логічному осмисленні долі окремої людини у загальному поступі людства. Так як культурологічний підхід у творенні науковопізнавальних текстів полягає у необхідності виробленні у студента потреби у самопізнанні, самостійній навчальній діяльності.

Доктор філологічних наук Н.В. Зелінська, “дослідивши масив української наукової літератури періоду іiі “другого відродження” (XIX - початку XX ст.) здійснила типологічно-жанровий аналіз видань та публікацій, виділила основні чинники та джерела формування репертуару наукової книги. Показала, що завдяки своїй особливій поетиці найкращі наукові праці того часу становлять не лише змістову, а й естетичну цінність. Обгрунтувала новий підхід до інтерпретації та оцінки наукових творів - 3 позицій поетики. Виявила зв'язок традицій української наукової літератури з моделями ефективного наукового тексту, які пропонує сучасна зарубіжна лінгвістика" [6].

Мова як духовно-екзистенційне явище живе у літературному тексті. Тому культурологічна компетентність вимірюеться не просто формуванням мовної, а у кожному конкретному випадкові мовленнєвої компетенції; а усвідомленням системи культурологічних поглядів, для формування яких літературний текст виступає важливим архетипом, на якому тримається духовне осереддя суспільства. Тягліть пракоренів, родинного вогнища виступає важливою основою духовного виховання і відповідного становлення нашого сучасника.

Висновки та перспективи подальших досліджень. Таким чином, можемо стверджувати, що у системі культурологічного засвоєння навчального матеріалу модернізація, інноваційне оновлення наукового тексту є важливо необхідним елементом, без якого неможливе якісне оновлення сучасної професійної освіти.

Роль підручника у системі сучасної вищої школи зростає у зв'язку з модернізацією навчальних планів і збільшення у навчальному процесі питомої ваги самостійної роботи студентів. У даному випадку підручник перестає бути просто джерелом інформації, а завдяки своїй інноваційній структурі $є$ носієм великого культурологічного впливу на свідомість студентів. Якісно новий тип підручників - важлива педагогічна проблема, без вирішення якої $є$ неможливим формування професійної компетентності сучасного фахівця.

\section{ЛІТЕРАТУРА}

1. Бех І. Д. Духовна особистість у контексті освітніх викликів. Рідна школа. 2019, №1.С.3-7.

2. Гончаренко С. У. Український педагогічний словник. Київ, 1997. 376 с.

3. Падалка О.С., Нісімчук А.М., Смоляк I.O., Шпак О.Т. Педагогічні технології. Київ, 1995. 248 с.

4. Ващенко Г. Хвороба в галузі національної пам'яті. Київ, 2003. 336 с.

5. Ушаков Л. Що таке українська література. Львів, 2015. 348 с.

6. URL: https://uk.wikipedia.org/wiki /

\section{REFERENCES}

1. Bech, I. D.(2019). Dykhovna osobustist u konteksti osvitnikh vyklykiv [Spiritual personality in the context of educational challenges]. Native school, No.1, pp.3-7. [in Ukrainian].

2. Goncharenko, S. (1997). Ukrainskyi pedahohichnyi slovnyk [Ukrainian Pedagogical Dictionary]. Kyiv, 376 p. [in Ukrainian].

3. Padalka, O.S., Nischimchuk, A.M., Smolyak, I.O. \& Shpak, O.T. Pedahohichni tekhnolohii [Pedagogical technologies]. Kyiv, 248 p. [in Ukrainian].

4. Vaschenko, G. (2003). Khvoroba v haluzi natsionalnoi pamiati [The Disease in the Field of National Memory]. Kyiv, 336 p. [in Ukrainian].

5. Ushakov, L. (2015). Shcho take ukrainska literature [What is Ukrainian literature]. Lviv, 348 p. [in Ukrainian].

6. Available at: https://en.wikipedia.org/wiki [in Ukrainian].

Стаття надійшла до редакції 23.10.2019

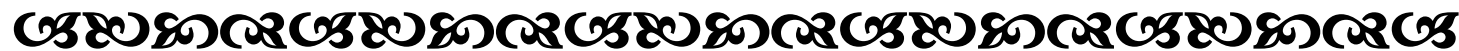

“Слова, що дають знання - найиінніші".

Apuстотель

давньогрецький білософ, вчений

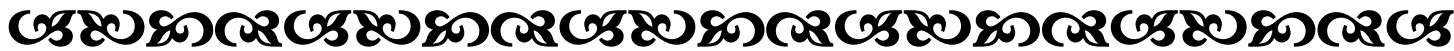

